This item was submitted to Loughborough's Research Repository by the author.

Items in Figshare are protected by copyright, with all rights reserved, unless otherwise indicated.

\title{
A systemic analysis of South Korea Sewol ferry accident - striking a balance between learning and accountability
}

PLEASE CITE THE PUBLISHED VERSION

http://dx.doi.org/10.1016/j.apergo.2016.07.014

\section{PUBLISHER}

(c) Elsevier Ltd.

\section{VERSION}

AM (Accepted Manuscript)

\section{PUBLISHER STATEMENT}

This work is made available according to the conditions of the Creative Commons Attribution-NonCommercialNoDerivatives 4.0 International (CC BY-NC-ND 4.0) licence. Full details of this licence are available at: https://creativecommons.org/licenses/by-nc-nd/4.0/

\section{LICENCE}

CC BY-NC-ND 4.0

\section{REPOSITORY RECORD}

Kee, Dohyung, Gyuchan Thomas Jun, Patrick Waterson, and Roger Haslam. 2016. "A Systemic Analysis of South Korea Sewol Ferry Accident - Striking a Balance Between Learning and Accountability". Loughborough University. https://hdl.handle.net/2134/22349. 


\title{
A Systemic Analysis of South Korea Sewol Ferry Accident - Striking a Balance between Learning and Accountability
}

\author{
Dohyung Kee, Gyuchan Thomas Jun, Patrick Waterson and Roger Haslam
}

*Corresponding author: Tel: +44 (0)1509 222663, Email: g.jun@lboro.ac.uk

\begin{abstract}
The South Korea Sewol ferry accident in April 2014 claimed the lives of over 300 passengers and led to criminal charges of 399 personnel concerned including imprisonment of 154 of them as of Oct 2014. Blame and punishment culture can be prevalent in a more hierarchical society like South Korea as shown in the aftermath of this disaster. This study aims to analyse the South Korea ferry accident using Rasmussen's risk management framework and the associated AcciMap technique and to propose recommendations drawn from an AcciMap-based focus group with systems safety experts. The data for the accident analysis were collected mainly from an interim investigation report by the Board of Audit and Inspection of Korea and major South Korean and foreign newspapers. The analysis showed that the accident was attributed to many contributing factors arising from front-line operators, management, regulators and government. It also showed how the multiple factors including economic, social and political pressures and individual workload contributed to the accident and how they affected each other. This AcciMap was presented to 27 safety researchers and experts at 'the legacy of Jens Rasmussen' symposium adjunct to ODAM2014. Their recommendations were captured through a focus group. The four main recommendations include forgive (no blame and punishment on individuals), analyse (socio-technical systembased), learn (from why things do not go wrong) and change (bottom-up safety culture and safety system management). The findings offer important insights into how this type of accident should be understood, analysed and the subsequent response.
\end{abstract}

Key words: sociotechnical systems, systems safety, accident investigation, AcciMap, Jens Rasmussen 


\section{Introduction}

On $15^{\text {th }}$ April 2014, the South Korea Sewol ferry carrying 476 people which included 325 high school students on a school trip, capsized and claimed the lives of over 300 passengers including the vast majority of students. In modern complex socio-technical systems like ships, which consist of complex and tightly coupled technostructures and their human operators, accidents are known to be caused by a variety of contributing factors including human, technical, organizational and social factors - not by just a single unusual decision or action of a specific actor (Shappell and Wiegmann, 2000; Heinrich et al., 1980; Reason 1995; Turner 1978; Vincent and Christoffersen, 2006; Waterson, 2009b).

On the contrary, accident investigation can be stuck on the old view, the Bad Apple Theory maintaining that safety problems are the result of a few bad apples (unreliable people) in an otherwise safe system (Dekker, 2014). This view focuses mainly on identifying human errors and violations, and blaming people concerned. Many Far East countries including South Korea have the culture that is characterised by ordering relationships by status and a strong sense of shame (Hofstede and Bond, 1988). In such culture that relies predominantly on hierarchical, compliance-based relationships, blame culture is more likely to occur (Khatri et al., 2009) as demonstrated in the aftermath of the South Korea ferry accident. More than a hundred people directly or indirectly related to this accident were legally put under arrest. Many high-rank officials including ministers of relevant governmental departments were dismissed or were under huge pressure to voluntarily resign their positions.

Historically, South Korea has rapidly and successfully developed its economy after Korean War in 1950s through intense and increasing competition, but its safety record is poor compared with other advanced nations (OECD, 2007). For example, there were five big accidents which led to more than 100 deaths over the past 20 years including the Sewol ferry accident: Seo-hae Ferry accident in 1993 leading to 292 deaths; Dae-gu subway gas explosion in 1995 leading to 101 deaths; Sam-pung Department store collapse in 1995 leading to 502 deaths and Dae-gu subway fire accident in 2003 leading to 192 deaths. After the accidents, people at the sharp end were usually held accountable and punished, but system level-lessons have hardly been learned. So, there is an urgent need for providing a framework for whole systems analysis for accident investigation.

Previous evidence clearly suggests that accident investigation should not focus on human errors and violations that triggered the accident, but on the mechanisms generating the errors and violations in the actual, dynamic socio-technical context (Branford, 2011; Rasmussen, 1997; Rasmussen and Svedung, 2000; Vincent and Christoffersen, 2006). In the dynamic socio-technical systems, accidents are actually waiting for its release, because the stage for an accidental course of events has been prepared over time by the normal 
efforts of working efficiently and cost-effectively by many actors in the daily work context. A quite normal variation in somebody's behaviour can ultimately release an accident (Rasmussen, 1997). Accidents are just the end result of a number of causes, only the last of which are the unsafe acts of actors (Bird, 1974; Heinrich et al., 1980; Reason, 1990; Shappell and Wiegmann, 2000).

Recently, several systems approaches, including the AcciMap approach, have been used for analysing accidents occurring in these complex socio-technical systems. These approaches capture and show varying contributing factors both from within different parts of the systems and interactions between them, and from external influences such as political, financial, and technological circumstances (Branford, 2011). Up to now, varying systems techniques have emerged including Swiss cheese model (Reason, 1990), Human Factors Analysis and Classification System (Shappell and Wiegmann, 2000), AcciMap (Rasmussen, 1997, Svedung and Rasmussen, 2002), FRAM (Hollnagel, 2004), STAMP (Leveson, 2004), etc.

Of various systems techniques for investigating accidents, the AcciMap was employed in this study due to the following reasons. Firstly, the AcciMap approach enables us to represent the multiple contributing factors and their relationships onto the levels of the socio-technical system. The diagram also depicts the context within which an accident occurred and the interactions that resulted in the event (Branford, 2011). It contributes to the explicit introduction of a much higher number of potential dimensions than those restricted to technical and human error. Secondly, its utility and benefits have been proven through frequent application in a broad range of fields such as aviation and space vehicles (Branford, 2011; Johnson and Muniz de Almeida, 2008), led outdoor activity (Salmon et al., 2010), public health sector (Vincente and Christoffersen, 2006; Woo and Vincente, 2003), road accidents (Svedung and Rasmussen, 2002), patient safety (Waterson, 2009a), and shooting accidents (Jenkins et al., 2010). Thirdly, it has provided theoretic basis of the work and thinking of many researches in the safety field (Amalberti 2001; Norman 1993; Reason 1990; Vincente and Christoffersen, 2006). Fourthly, it does not only explain why accidents occurred, but also reveals how they might be prevented by providing a useful platform for communication with the various disciplines (Rasmussen and Svedung 2000; Svedung and Rasmussen 2002; Vincente and Christoffersen, 2006; Jenkins et al., 2010).

The objectives of this study were to analyse systematically the South Korea ferry accident using the AcciMap and to capture recommendations from a group of system safety experts with whom the AcciMap analysis results were shared. This study introduces a novel way of using the AcciMap not only as an analysis tool, but also as a representation for communicating complicated accident mechanisms and drawing recommendations from a group of safety experts. This study provides an important opportunity to advance the 
understanding of a complex socio-technical failure in a more hierarchical culture. It also offers some important insights into how this type of accident should be analysed and responded in a country like South Korea. 


\section{Methods}

\subsection{Accident analysis}

The data for the accident analysis were collected and validated from the following three sources: i) Interim post-accident report by the Board of Audit and Inspection of Korea (BAI); ii) news articles, columns and editorials in major South Korean and foreign daily newspapers, news magazines and broadcasting medias between April 2014 to October 2014 including Chosun-ilbo, Donga-ilbo, Yonhap News, Weekly/Monthly Chosun of Korea, the Financial Times of UK, and CNN of USA; iii) personal consultation with a senior operation manager in an international shipping company.

The accident received very intense media coverage for several months so there was no shortage of articles. Relevant data were searched based on the keywords of 'Sewol ferry cause', 'Sewol ferry preventive measure,' which resulted in hundreds of articles. Of those, around a hundred articles that seemingly covered the accident's causes and timeline, etc. were selected from reliable sources. After reading all the selected articles, 35 articles (included in Appendix) were finally chosen and used in the later analysis. Some facts and figures were validated through multiple sources.

Two authors of this paper with human factors background and significant experience in the AcciMap method conducted an AcciMap analysis of the accident. This was internally validated by the remaining co-authors and externally validated by the senior operation manager in a shipping company. The AcciMap analysis involved the construction of a causal diagram, which maps the multiple contributing factors to the accident and their interrelationship on the five levels of the sociotechnical system. In this study, the structure of the AcciMap has been adopted from Svedung and Rasmussen (2002) and Branford (2011). Starting from outcomes of the accident at the bottom of the graph, five levels include physical/actor events, processes \& conditions, technical \& operation management, company management, regulatory bodies \& association, and government \& environment.

\subsection{Recommendations by safety experts}

With the aim of drawing recommendations from a group of system safety experts, a focus group was carried out. The AcciMap produced from the analysis was presented at 'the legacy of Jens Rasmussen' symposium, Adjunct Symposium of Organisation Design and Management (ODAM) conference 2014. The key aim of this symposium was to generate discussion and debate in the light of Rasmussen's work about the new directions and the future of safety science. Twenty five to thirty safety experts from all over the world (UK, US, France, Sweden, Denmark, Germany, Australia and Japan), both practitioners (risk and safety management consultancies and government agencies) and researchers (universities 
and research institutes) attended this symposium. Most of them had experience working with or were influenced by Jens Rasmussen.

The audience were given a form with open space prior to the presentation. They were asked to write down any recommendations to government, industry, regulators, and general public in South Korea while listening to the presentation. After a 20 min presentation explaining the accident background and contributing factors using the AcciMap, further 30-40 min group discussion was carried out around their suggestions and recommendations for safety improvement. Thirteen participants returned the completed written form with various recommendations and a thematic analysis on their comments was performed. The participants included nine senior academics, two researchers and two practitioners in the field of systems safety and risk management in various sectors (healthcare, nuclear, oil \& gas, etc).

\section{Results}

\subsection{Timeline}

On 15 April 2014, the Korean ferry of the Sewol left Incheon port for Jeju island. About 14 hours after its departure, the ferry capsized in the sea $3.3 \mathrm{~km}$ north Byungpoong island (narrow waterway called the Maenggol Strait) with treacherous currents. The detailed accident timeline appears in Table 1.

Table 1. Timeline of the Sewol ferry accident

\begin{tabular}{l|l}
\hline Time & Event/Activity \\
\hline $\begin{array}{l}\text { October } \\
\text { March 2013 }\end{array}$ & $\begin{array}{l}\text { Cheonghaejin Marine Company purchased an used ferry with age of 18 } \\
\text { years (called 'Sewol' later) from Japan. } \\
\text { Port Administration and Sewol began its operation. }\end{array}$ \\
\hline $\begin{array}{l}\text { 21:00 PM } \\
\text { 15 April 2014 }\end{array}$ & $\begin{array}{l}\text { Sewol ferry left Incheon port for Jeju Island (150 minute delay from the } \\
\text { scheduled time of departure due to foggy weather). }\end{array}$ \\
\hline $\begin{array}{l}\text { 08:48 AM } \\
\text { 16 April 2014 }\end{array}$ & $\begin{array}{l}\text { The vessel began to list to port with booming sound and rapidly decelerated } \\
\text { from 35km/h to 14km/h. }\end{array}$ \\
\hline $\begin{array}{l}\text { 08:52 AM } \\
\text { 16 April 2014 }\end{array}$ & $\begin{array}{l}\text { A boy student on board contacted Chonnam Fire Service (119 emergency } \\
\text { service) to report the accident using his mobile phone. }\end{array}$ \\
\hline $\begin{array}{l}\text { 08:55 AM } \\
\text { 16 April 2014 }\end{array}$ & $\begin{array}{l}\text { The first navigating officer reported a distress situation to Jeju Vessel Traffic } \\
\text { Service (VTS). }\end{array}$ \\
\hline
\end{tabular}




\begin{tabular}{|c|c|}
\hline & $\begin{array}{l}\text { The second navigating officer made on-board announcements several times } \\
\text { not to move from passengers' location. }\end{array}$ \\
\hline $\begin{array}{l}\text { 08:56 AM } \\
16 \text { April } 2014\end{array}$ & $\begin{array}{l}\text { Jeju VTS replied to the distress report and ferry's crew asked for a rescue } \\
\text { team. }\end{array}$ \\
\hline $\begin{array}{l}\text { 08:57 AM } \\
16 \text { April } 2014\end{array}$ & $\begin{array}{l}\text { Jeju VTS disseminated the distress situation and requested the coast } \\
\text { guard's urgent rescue of the ferry. }\end{array}$ \\
\hline $\begin{array}{l}\text { 09:00 AM } \\
16 \text { April } 2014\end{array}$ & $\begin{array}{l}\text { Jeju VTS told an unidentified crew member to get ready for abandoning the } \\
\text { ship, but the crew member replied that the passengers cannot due to listing. }\end{array}$ \\
\hline $\begin{array}{l}\text { 09:04 AM } \\
16 \text { April } 2014\end{array}$ & $\begin{array}{l}\text { A Sewol crew member reported the distress situation to Mokpo coast guard, } \\
\text { but the coast guard did not take any action. }\end{array}$ \\
\hline $\begin{array}{l}\text { 09:05 AM } \\
16 \text { April } 2014\end{array}$ & $\begin{array}{l}\text { A Sewol crew member asked Jeju VTS about the rescue activity and Jeju } \\
\text { VTS replied to wait for it. Up to this time, a crew member repeatedly } \\
\text { announced that passengers should stay put in the safe cabin. }\end{array}$ \\
\hline $\begin{array}{l}09: 07-37 \\
\text { AM } 16 \text { April } \\
2014\end{array}$ & $\begin{array}{l}\text { Jindo VTS communicated with a crew member on the ongoing situation of } \\
\text { the vessel. }\end{array}$ \\
\hline $\begin{array}{l}\text { 09:39 AM } \\
16 \text { April } 2014\end{array}$ & Eight engine crew members escaped from the vessel. \\
\hline $\begin{array}{l}\text { 09:46 AM } \\
16 \text { April } 2014\end{array}$ & $\begin{array}{l}\text { Seven crew members including the captain and first engineer escaped from } \\
\text { the vessel. }\end{array}$ \\
\hline $\begin{array}{l}\text { 10:25 AM } \\
16 \text { April } 2014\end{array}$ & The vessel listed by more than $90^{\circ}$ to port. \\
\hline $\begin{array}{l}\text { 11:20 AM } \\
16 \text { April } 2014\end{array}$ & The vessel sank completely. \\
\hline 11 Nov 2014 & Search activity for the missing ended. \\
\hline
\end{tabular}

\subsection{AcciMap Analysis Results}

The Sewol ferry accident resulted in loss of over 300 lives including nine missing, which was attributed to the combination of the capsizing accident of the ferry and shortcomings with the rescue operation after the incident. The poor rescue operation missed many opportunities to minimize human loss. The accident analysis is divided into two parts of the capsizing of the ferry and the rescue operation. They are represented separately in Figure 1 and Figure 2, and analysed in 3.2.1 and 3.2.2.

\subsubsection{Capsizing of the Ferry}

Figure 1. AcciMap of the capsizing of the Sewol ferry 


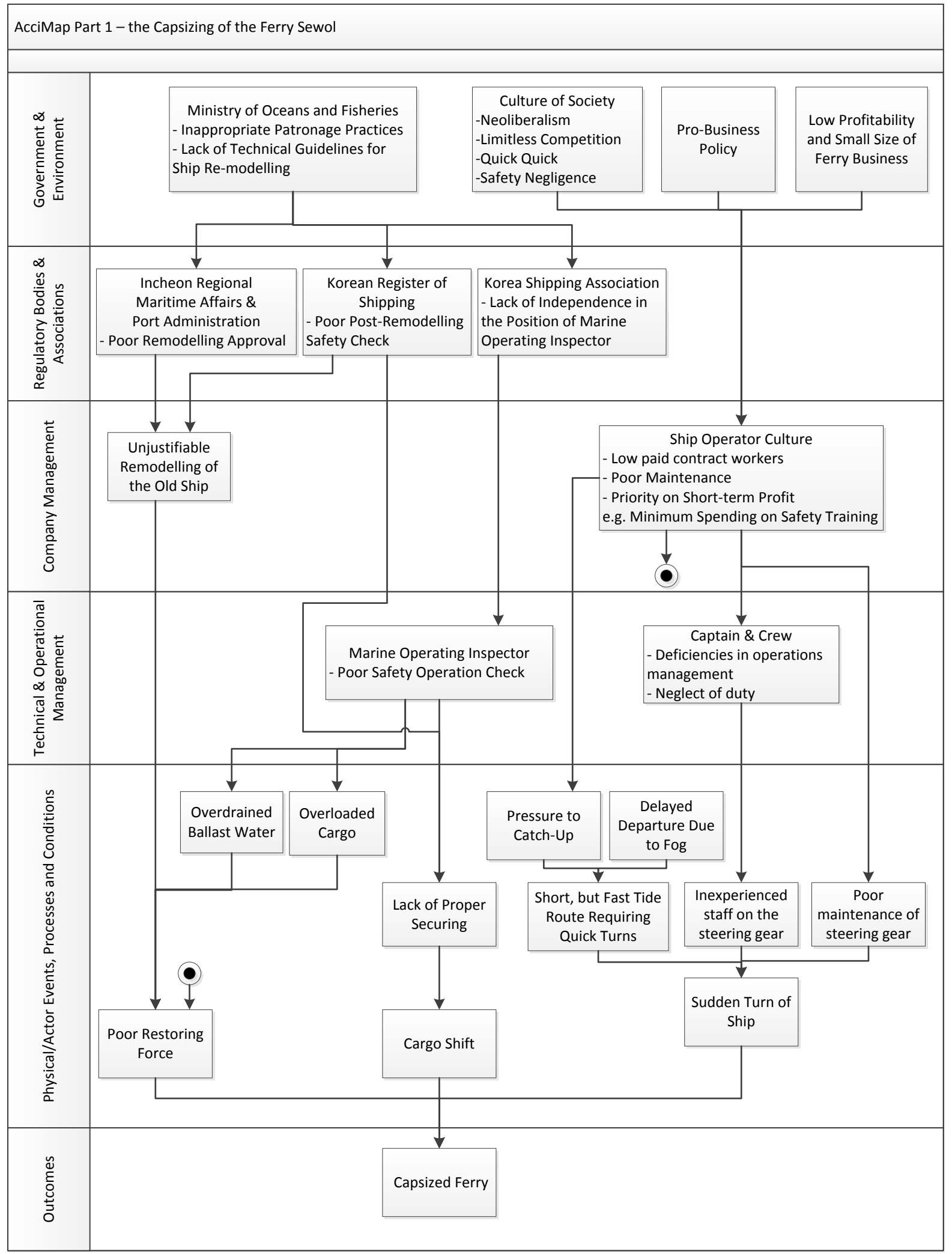




\subsubsection{Physical processes \& actor activities}

As the second bottom row of the AcciMap (Figure 1) indicates, three physical conditions, events and processes directly contributing to the capsizing were identified: poor restoring force (condition), shift of improperly secured cargos (event) and sudden turn of the ship (process). First, the restoring force is the ship's capacity to return to a stabilised position after being destabilised. At the time of the capsizing accident, the Sewol's restoring force was significantly reduced mainly due to three unsafe conditions: unjustifiable remodelling, deliberately over-drained ballast water (less than that required by the loading condition) and overloaded cargo. The operating company of Chonghaejin Marine Company purchased the ferry in 2012 from Japan. They remodelled it to raise passenger capacity by 116 (from 840 to 956) and ended up with increased gross tonnage by 239 t (from $6,586 \mathrm{t}$ to $6,825 \mathrm{t}$ ). The company added extra passenger cabins and an art gallery on the third, fourth and fifth decks of the stern. This remodelling shifted the ferry's centre of gravity upwards and to the stern and therefore the cargo weight limit was reduced by $1,360 t$ (from $2,437 \mathrm{t}$ to $1,077 \mathrm{t}$ ). Ignoring this new cargo weight limit, the ferry, when it capsized, was carrying almost twice its limit cargo weight as shown in Table 2. In order to compensate its cargo overload, a crew member had a practice of over-draining the ballast water carrying only about $43 \%$ of the standard quantity as specifically shown in Table 2.

Table 2. Overloading and over-draining of the Sewol

\begin{tabular}{cccc}
\hline & $\begin{array}{c}\text { Standard } \\
\text { (limit/required) }\end{array}$ & $\begin{array}{c}\text { Conditions } \\
\text { at the accident }\end{array}$ & Changes made \\
\hline Cargo loaded & $1,077 \mathrm{t}$ & $2,142 \mathrm{t}$ & $+1,065 \mathrm{t}$ overloading \\
\hline Ballast water & $2,418 \mathrm{t}$ & $1,042 \mathrm{t}$ & $-1,376 \mathrm{t}$ over-drained \\
\hline
\end{tabular}

This unsafe operation was possible since marine operating inspectors examined the loading condition only by visually checking the load line on the hull of the ferry. The crew members noticed the ferry's balance problem a few months before the accident and reported it, but company officials did not respond to it. Some dockworkers also said that the ferry was so unstable that it lurched badly during loading and unloading. In summary, the combination of the reduced ballast water and overloading of the cargo raised the ferry's center of gravity upwards and made it more prone to tip due to its reduced restoring force.

Second, the lashing devices that should have held cargo goods steady were found to be loose. The task of securing cargos was sub-contracted to an unlicensed company and some crew members did not even know how to use the lashing devices correctly. Stacks of cargo containers were in a condition that they could slide down to one side easily. It meant that they failed to implement the provision of the Sewol's sailing control regulation, which was 
written by the company and approved by the Ministry of Oceans and Fisheries (MOF). It read that crew members should tightly secure cargo goods before departure using belts or iron chains with safety factor of over 4.0 .

Third, the sudden turn of the ferry made by an unexperienced navigating officer significantly contributed to the capsizing. The ferry's departure was delayed by about 2.5 hours due to thick fog at the departing port (Incheon port). To catch up the delay, the captain selected the fast tide (about $0.39 \mathrm{~m} / \mathrm{s}$ ) but short seaway, called Maeggol Strait, instead of taking a routine route. The captain wanted to take a break and happened to leave an inexperienced third navigating officer to navigate the risky route on his own. The third navigating officer had been with the company only for six months at the time of accident. It was later revealed that he actually was banned from navigating a ship when entering and departing a port on account of his previous navigating mistake in December 2013. Furthermore, according to the daily log for repair, a problem with the steering gear had been reported 15 days before the accident, but was not addressed. After the accident, the third navigating officer acknowledged his mistake but pointed out that the steering turned so much faster than usual. In summary, three main factors that contributed to the sharp and sudden turn of the ferry were inexperience of the third navigating officer, poor functioning of the steering gear and fast tide.

In turn, this made poorly secured cargoes and containers fall over and the ferry's weight thrown to the left side, which resulted in the ferry listing to the left. The ferry's listing was not restored to normal because of reduced restoring force due to the changes to the vessel design, overload and lack of ballast water. Consequently, the ferry listed more rapidly than usual, and completely sank in the sea in less than three hours, although a ship of that size should have taken several hours to sink.

\subsubsection{Technical \& operational management}

The main contributing factors at this level include poor management of two groups of actors: the marine operation inspector and the crew members including the captain. According to the Enforcement Regulation of the Marine Transportation Act, marine operation inspectors are responsible for inspecting the number of people on-board, quantity of cargoes, status of secured cargoes and life-saving appliances before every departure. However, the inspection conducted by the marine inspector was superficial. He only checked the load line on the hull from a distance and checked the remaining safety issues based on the written document self-reported by the captain. These inspection practices without any on-board examination gave plenty of room for safety violation in various aspects of the operation.

Deficiencies in the crew members' operations management also had a significant impact on the capsizing. The captain ignored the Seafarers Act of Korea saying that the captain should 
directly navigate ships when accessing a port or sailing a narrow waterway or when there is a possibility of risk on ships. Instead, the captain left the inexperienced third navigating officer alone at the bridge when passing the dangerous seaway of Manggol strait.

In addition, the captain failed to perform two important duties: inspecting on-board life-saving appliances such as life rafts; conducting safety education and emergency training for his crew members. These duties are prescribed in the Enforcement Regulations of the Marine Transportation Act and the Seafarers Act, respectively.

\subsubsection{Company management}

At this level, the capsizing was related to organizational influences such as Chonghaejin Marine Company's culture: priority on short-term profit, employment of low-paid contract workers and prevalence of operational and safety oversights. The company had given priority to the pursuit of short-term profit for the owner's family; it was revealed that there were illegal flows of money to the company owner's family members. The following four examples illustrate the company's culture.

First, the company inappropriately and illegally modified the Sewol in 2012 to make more room for passengers. The company submitted falsified documentation to gain remodelling approval from the Incheon Regional Maritime Affairs \& Port Administration (RMA\&PA), which is a ship remodelling authorization governmental branch of the Ministry of Oceans and Fisheries (MOF). In the falsified document, the company raised Sewol's average revenue per trip to get the authorization for the expansion.

Second, since the company started to run the Incheon to Jeju route in March 2013, the ship routinely carried more cargo than allowed in $57 \%$ of its trips (139 out of 241 trips). The company was estimated to have earnt an extra profit of \$2.9 million from overloading. Some dockworkers on Jeju port once held a demonstration in front of the local governmental office to complain that the ferry company was putting more cargo on the Sewol than it reported in cargo manifests. The complaint was made because the dockworkers, who were paid by the ton, were paid less due to the understated amount of cargo.

Thirdly, in order to save operating costs, the employment of crew members was based on temporary contracts. Their contracts were usually renewed, but they had low salary and low job security compared to crew members in other marine companies in Korea. The Sewol's senior crew members including the captain and officers were also temporary contract workers. The captain at the time of the accident was standing in for another fulltime captain who was on annual leave. 
Fourthly, the company management did not respond to safety problems. Before the accident, crew members, including the full-time captain of the Sewol, reported problems with its restoring force and steering gear to the company management, but it was disregarded. Instead, the company executives requested crew members to load as much cargo as possible.

\subsubsection{Regulatory bodies \& associations}

The contributing factors at this level included poor authorisation processes of the ferry's expansion and lack of independence in inspection. Firstly, the Incheon Regional Maritime Affairs \& Port Administration (RMA\&PA) and the Korean Register of Shipping (KRS) wrongly approved the application of the Sewol's remodelling submitted by the ferry's operating company. The Incheon RMA\&PA authorized the Sewol's remodelling based on the falsified document without comparing it with the original document written by a Japanese Ship Inspection Institute before the ferry purchase.

The KRS is a private organisation licensed by the government to carry out a task of certifying new design as seaworthy. The KRS licensed the remodelling under the condition that the company should set limits on the maximum amount of cargo and the minimum amount of ballast water when fully loaded. It assigned an inspector to ensure that the remodelling was done correctly. However, the inspector approved the remodelling without properly conducting an inclining test to determine whether the remodelled ship was sufficiently stable. The inclining test was conducted on the basis of the falsified documents submitted by a private design company. The design company reported an 100 ton-underestimate of the light weight of the ship (actual weight of the ship with no fuel, passengers, cargo, water and the like on board) and 436 ton-reduced cargo weight from 1,513t to 1,077t to meet the acceptance criteria of its remodelling. If the inclining test had been done on the basis of the correct data, the Sewol's remodelling could have not been approved. The company also submitted an impractical securing layout and the KRS negligently accepted it without a walkthrough examination.

Secondly, there was a structural problem in the independence of the marine operation inspection. The Korea Shipping Association (KSA) is an industry group funded by the marine companies. Ironically, one of the KSA's responsibilities was to monitor the operation safety of marine companies. Critics of the maritime safety system had said long before the accident that the KSA should not monitor safety because it has a built-in conflict of interest. It was reported that the KSA had proposed to the Ministry of Oceans and Fisheries (MOF) that the marine operation inspection tasks should be transferred to the MOF several times, but the proposal was not accepted. 


\subsubsection{Government \& environment}

The contributing factors at this level included failings of the MOF officials, loopholes in ship remodelling related laws and Korea's social environment. There was wide-spread inappropriate patronage in high positions in the government-affiliated or supporting organisations. It was reported that former officials retired from the MOF took charge of head officials for 11 of 14 MOF-affiliated or supporting organisations including Korea Shipping Association, Regional Maritime Affairs \& Port Administration and Korea Ship Safety Technology Authority as of May 2014. The MOF entrusted various safety-related tasks such as ship inspection, authorizing ship expansion, marine environment and port management and seafarer education to those affiliations, but the MOF did not tightly manage and oversee them due to the long standing relationships between officials. This might have influenced the action of wrongly licensing the Sewol's remodelling and poorly checking its overload by the Korean Register of Shipping and the Korea Shipping Association.

With regard to ship remodelling related law, there were no well-defined provisions that restrict a ship's inappropriate remodelling, especially its height expansion. There is a provision in the Ships Safety Act that the MOF's permission is required when expanding ships' length, width and depth, while there is none for a ships' height expansion. Due to this loophole, the Incheon RMSA\&PA, the responsible organization for authorizing ship remodelling, made a mistake of approving the Sewol's unreasonable expansion in height. The unique social environment of Korea was also thought to indirectly contribute to the accident. Among the ultimate factors contributing to the ferry accident, there might have been an economic model of neo-liberalism that prizes economic growth and profits above the welfare of citizens. It is often said in Korea that economic growth is everything and quality of life can be sacrificed. This might have brought about Korea's intensely competitive society, quick-quick culture and culture of safety negligence. A further consequent of government pro-business policies was an increased prevalence of temporary contract-based low paid workers.

\subsubsection{Poor Rescue Operation}

The poor rescue operation after the capsizing is considered as another major factor for the loss of many lives. Figure 2 captured various contributing factors to the poor rescue operation.

\subsubsection{Physical processes \& actor activities}


The poor rescue operation was attributed to several unsafe conditions, events and processes: poor initial measures by crew members (process), confusing exit routes (condition), problems with on-board life rafts (condition), delayed report to authorities and arrival of rescuers (process) and poor initial rescue operation (process).

Firstly, the poor initial measures by crew members wasted an opportunity to save more passengers after the capsizing. At the time of the accident, passengers were told to stay in the safe cabin as frequently as seven times between 8:55AM and 09:50AM while the ferry began its descent into the sea. Many passengers complied with the announcement without knowing that the ferry was sinking. In this situation, some students shouted, "This is fun!", and joked about posting the event on Facebook. The captain asserted later that the decision not to evacuate passengers was based on the strong tidal current, cold water temperature and no arrival of rescue boats at that time. Between 09:39AM and 09:46AM, the captain and several crew members abandoned the ferry without helping passengers escape from the capsizing ferry. Fifteen crew members including the captain were among the first group of people saved.

The crew members' communication and coordination with other stakeholders were poor. At 08:55AM, the first navigating officer reported a distress situation to Jeju Vessel Traffic Services (VTS) Centre. At 08:58AM, the captain ordered the second navigating officer to make an announcement that passengers should don the life vests and wait in the cabin. The second navigating officer tried to announce it, but failed to do so because he forgot to press an emergency button necessary for the announcement. At 09:00AM, a Jeju VTS official instructed the Sewol that you should prepare to abandon the ferry, but crew members did not respond to the instruction. At 9:25AM, another VTS official based in Jindo told the Sewol that you should let passengers put on life vests and prepare to evacuate them based on captain's judgment. However, the captain did not make any decision and missed an opportunity to evacuate passengers. In the radio communication with the VTS, a crew member, without taking any action, just asked the VTS about whether or not the passengers could be rescued immediately in case of abandoning the ship.

Secondly, narrow and confusing corridors made it more difficult for passengers to escape from the ferry by themselves. Due to several illegal design changes, the internal layout was different from that of the original drawing and became very complicated. 


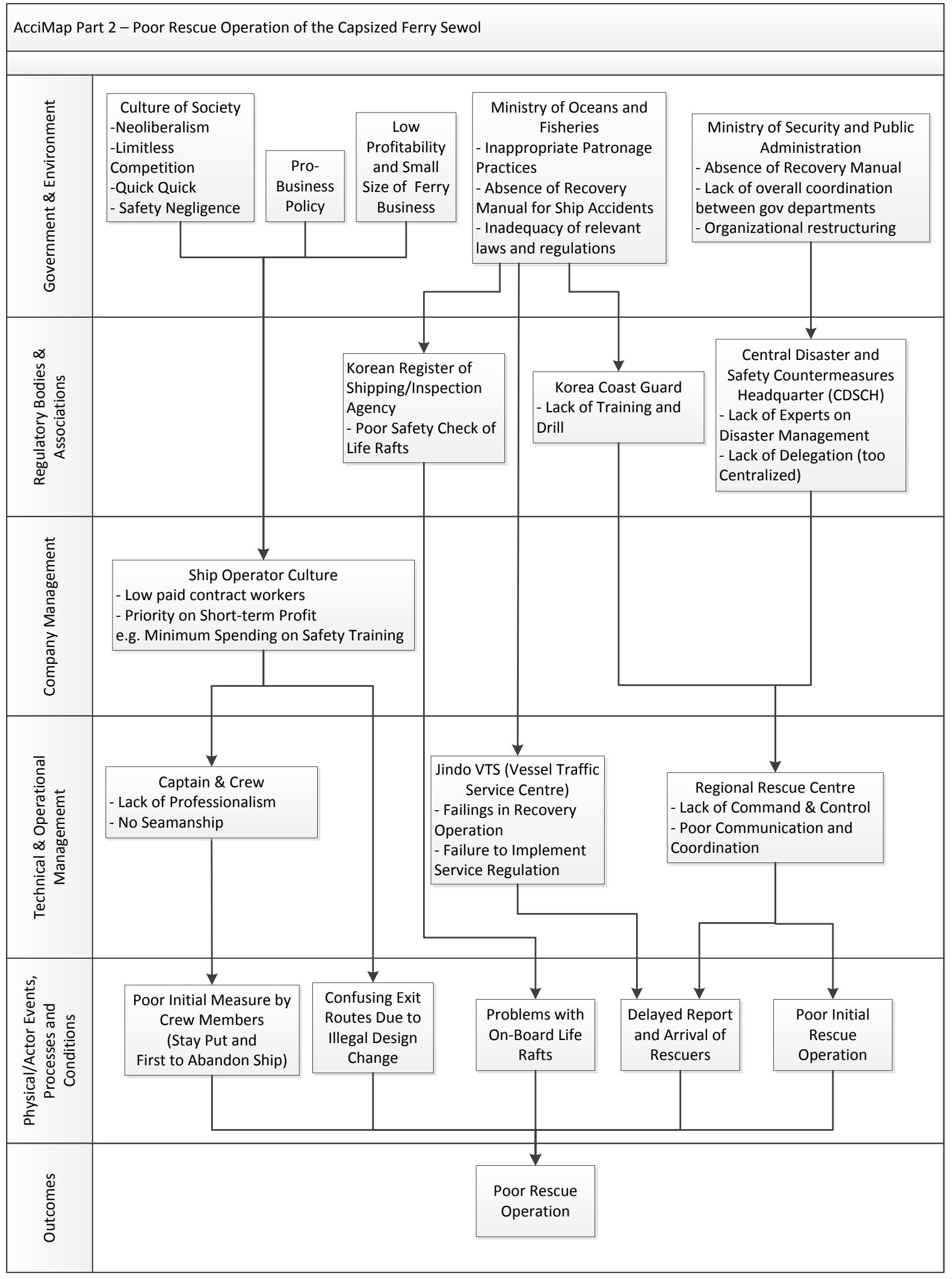

Figure 2. AcciMap of the poor rescue operation 
Thirdly, the life rafts of the ferry were hardly used in the accident. The ferry was equipped with 44 life rafts, each having boarding capacity of 25 . This capacity met the requirement and the inspection document said that all the life rafts passed periodical inspection tests. However, only one of the 44 life rafts was automatically released at the time of the accident. Fourthly, due to delayed accident reporting and subsequently delayed dispatching of rescue teams, the precious time for initial action was wasted. The first distress call came from a student on board who contacted the emergency service of a regional (Jeonnam province) Fire Service at 08:52 AM using his mobile phone. The dispatch of a fire helicopter emergency service was delayed because the fire service considered that marine accidents were outside their jurisdiction, but the jurisdiction of the KCG. At 08:55 AM (three minutes after the first distress call), a first navigating officer made a distress call to Jeju VTS, not to Jindo VTS which is near the accident site. This miscommunication contributed to delayed dispatch of rescue teams.

Fifthly, poor initial rescue operation by on-site rescue teams led to far more sacrifice of passengers. The KCG rescue team which firstly arrived at the accident area could see the trapped passengers through the right side windows of the $60^{\circ}$-listed ferry. However, they could not rescue them in time because they did not have ropes and climbing equipment for the rescue. At the end, the rescue teams focused on rescuing a relatively small number of passengers visible and floating on the sea, who escaped the ferry themselves.

\subsubsection{Technical \& operational management}

The contributing factors at this level include deficiencies in the actions of crew members and VTS operators, and poor control, coordination and communication between different organisations.

Firstly, crew members' actions significantly contributed to the poor initial rescue operation. Most crew members did not show expected seamanship in prioritizing passengers' safety over their own lives. The Sewol's captain as well as some crew members abandoned the ship before most passengers, while passengers were told to stay inside safe cabins. They violated the provision of the Seafarers Act that captains should not leave ships under their control from the time cargo starts to be loaded or passengers start to board to the time unloading of cargo and disembarking of passengers are completed. They also ignored an evacuation procedure of the Sewol's sailing control regulation prescribing that the first and second navigating officers should help passengers escape a ship to its right and left, respectively, and that the helmsman and engineers should release the life rafts on both sides of a ship. Furthermore, the rescued crew members did not immediately let rescue 
teams know their identities, let alone information on the situation of confined passengers in the ferry.

The VTS' failings contributed to the poor initial rescue operation. One of the most important roles of the VTS is to provide swift responses and communication for marine accidents and emergent situations. However, Jindo VTS was not competent in giving the Sewol's crew members any concrete and prompt measures for the distress situation. For example, Jindo VTS understood the emergent situation in the ferry after 31 minute communication with its crew member (09:07AM 09:37AM). However, Jindo VTS repeatedly said to the crew member, "Properly handle all things related to rescuing based on the captain's judgment" without giving any appropriate measure or order such as abandoning the ferry or assembling passengers on deck. In addition, the VTS did not notify the emergent situation to the on-site rescue teams and the rescue centre.

Jindo VTS officials' shortcomings in monitoring and control also prevented early detection of the Sewol's abnormal symptom of listing. It was revealed that the controllers of Jindo VTS had been ignoring the service regulation that two controllers should be at work simultaneously; one has a duty to control the coastal sea and the other to control the offing sea. For more than one month before the accident, only one controller had been on duty and controlled both coastal and offing seas during night. It was estimated that the early detection could have made the rescue operation start five minute earlier which might had led to rescuing more passengers.

Another problem in the rescue operations was the rescue centre's failings in command and control. The rescue centre was a temporal organization with special purpose of commanding and coordinating rescue activities when major accidents occurred. Firstly, the rescue centre was under a hierarchical organisational structure (narrow region, wide region and national) and had consequently a long chain of command and control. The rescue activities were delayed partially because they had to spend too much time in reporting the accident to higher authorities and awaiting their orders.

Secondly, the quality of command and control was also poor. The rescue centre ordered rescue teams to move to the accident area without giving important information such as the number of passengers, location of passengers, degree of the ferry's sinking, means of transportation and ways of cooperation between rescue teams. This lack of information resulted in ineffective rescuing activities.

Even after the rescue centre became aware that most passengers had been waiting in the cabins, the centre did not instruct rescue teams to guide passengers to escape. Furthermore, in spite of the on-site rescue teams' urgent report that the ship might sink soon, the regional 
rescue centre ordered the rescue teams to put the passengers at ease so that they would not feel unrest, rather than to guide them to abandon the ship.

\subsubsection{Company management}

The main factors at this level were deficiencies in the company's emergency training for their staff, both ferry crew and rescue team members. The ship operating company put profit above safety and minimised costs of safety training. In fact, the crew members had never received evacuation drills, and were inadequately prepared to deal with an emergency. It was also revealed that the financial pressure of the company was partially due to the fact that the company owner siphoned at least $\$ 33$ million away from the company to his son's company abroad.

\subsubsection{Regulatory bodies \& associations}

The contributing factors at this level include inadequate management of inspection of the Sewol's life raft by Korean Register of Shipping/Inspection Agency (KRS), lack of training by the Korea Coast Guard (KCG) and lack of experts in disaster management in Central Disaster and Safety Countermeasures Headquarter (CDSCH).

At the first stage, a government-licensed private company inspected whether the ship's life rafts operated normally. The company sampled just nine out of forty four life rafts and conducted rough-and-ready inspections within two days. It generally takes about 15 days to inspect all 44 life rafts. The final approval by the KRS was based on the company's fabricated inspection report claiming that all of the 44 life rafts were in good order. At the accident, only one raft was released correctly.

The KCG did not train its rescue workers for ship capsizing accidents. In addition, they did not have any rescue equipment for this capsizing situation. Some KCG rescue workers admitted in the court that they were not properly-acquainted with contents of the marine accident manual written by the Ministry of Oceans and Fisheries.

Lack of experts in disaster management in Central Disaster and Safety Countermeasures Headquarter ( $\mathrm{CDSCH}$ ) led to poor communication and coordination. The $\mathrm{CDSCH}$ is a temporary command and control centre for the management of disaster situations under the Ministry of Security and Public Administration (MSPA). The CDSCH officials were dispatched from relevant governmental organizations including the MOF, the MSPA, etc. However, there was no operating manual and they had not received any training for marine accidents, so they were not clear about their roles and confused with what to do. In addition, the $\mathrm{CDSCH}$ cited unchecked media reports and mistakenly announced that all the students on-board were rescued and that rescue teams had succeeded in entering the Sewol to save 
passengers at the early stage of the disaster. This announcement later proved untrue and the government lost its trust from the public.

\subsubsection{Government \& environment}

Absence of relevant recovery manuals for marine accidents and lack of overall coordination between government departments contributed to poor initial response. Korean government neglected to make and maintain manuals for marine accidents, and to train relevant personnel according to the manuals. Specifically, the MSPA did not provide an operating manual for the $\mathrm{CDSCH}$.

The CDSCH's confusion with initial responses to the accident might have been attributed to its recent organisational restructuring several months before the disaster. The responsibility for man-made disaster management was transferred to the $\mathrm{CDSCH}$ from the National Emergency Management Agency in August 2013. The aim was to strengthen the commanding and adjusting functions for the disasters. However, by the time of the disaster, its structure and personnel needed to conduct the duties had not been fully transferred from relevant government ministries. At the beginning of the accident, the CDSCH's focus was on media briefings, which were conducted six times at hourly interval, instead of much more important duties of commanding and adjusting the disaster countermeasures such as grasping the disaster status, searching for available rescue sources, administrative support, etc.

Furthermore, two governmental agencies, the $\mathrm{CDSCH}$ and $\mathrm{KCG}$, presented different figures on the same item or wrong information without mutual discussion and confirmation of facts. This confusion provoked anger and distrust of the general public. For example, while the KCG reported 477 passengers on board, 61 rescue ships and 8 helicopters dispatched on the site, the $\mathrm{CDSCH}$ reported 476 passengers on board, 34 rescue ships and 19 helicopters dispatched.

\subsection{Recommendations by safety experts}

Forty minute long discussion was carried out after the 20 min AcciMap presentation and written feedback was provided by 12 participants after the discussion. The comments were categorised into four topics: forgive; analyse; learn; change. First of all, almost half of the respondents (54\%) emphasized the importance of forgiving people in such a systemic complex disaster and warned of the potential negative impact of simple blaming/punishing. One respondent very strongly stated that blaming/punishing people and improving safety are mutually exclusive options. Secondly, the importance of applying a socio-technical systems approach and human cognitive mental model-based approaches in accident investigation was mentioned by almost half of the respondents (46\%). In addition, the importance of 
independent and early investigation by experts was mentioned (23\%). Thirdly, the potential benefit of the Safety II approach, learning from why things go right instead of why things went wrong, was mentioned (31\%). Fourthly, both changes in top and middle level such as government policies, regulations (54\%) and bottom-up cultural changes by frontline workers and general public (31\%) were mentioned. The importance of development of appropriate safety/accident/disaster management system, e.g. training courses and materials and regular implementation of them, also featured (31\%).

Table 2. Recommendations by safety experts

Categories

(\% of respondents)

Respondents' comments

Forgive

No blame /

No punishment

- Punishment should be avoided as much as possible.

- Looking for and finding people to blame will not stop the next terrible accident from happening.

- Striving towards a society that can account for and forgive human shortcomings should be the long term goal.

- Emphasize that blame \& punishment \& removing people will not prevent a recurrence of the accident unless underlying causes are addressed.

- Blame is a really short-term measure which does not solve the basic long-term problem

- When error occurs, go for the problem, not the person.

- You can choose only one option between punishing people and improving safety. You can't have both.

\section{Analyse}

Systems perspective and system failure $(46 \%)$

- Learn about the socio-technical system that leads to the accident (organisational, technical, environmental and personal factors)

- It is evident that there is a complex network of factors that influence and drive an event, that exist independently of the individuals involved.

- Avoid simplistic models to explain accidents such as "human error" and a systems perspective is needed, i.e. human, technology, organisation perspectives.

- This is a classic system incident.

- Investigators need to understand human cognitive mental models and decision making under degraded conditions.

\section{Analyse}

Investigation approach
- Independent accident investigation by experts is important.

- Conduct investigation interviews as early as possible to get the bottom of what happened.

$(23 \%)$

Learn

Safety II approach
- It may help to invert the inquiry into this accident. Instead of asking "why did this happen?" ask "why doesn't this happen often?" The usual findings are that there are many more opportunities to fail than there are actual failures. Why does the system work so well? What are people doing that usually prevents such accidents?

- "The other story" about the resilience is the system that needs to be upheld and not eroded. What can we learn from what works and how can we strengthen that?

- Look at positive factors affecting accident prevention/recovery during the 
normal operation of the system

- One way forward is to move focus from what went wrong and why, to what is supposed to work and how. That would be in line with the core ideas of high reliability organisations, e.g. organisational mindfulness. Recently, the same ideas have been re-labelled with "resilience engineering" as safety I and safety II and the likes. Such a shift of focus is one (of many) way to transit from retrospect to proactive future orientation that might aid learning (instead of blame)

\section{Change} middle level recurrent causal/ contributing/control/re strictive factors
Focus on high or

- Need to focus on underlying factors which influence likelihood of many error in different accidents

- All accidents involve multiple causes. However many of these causes may be influenced by a small number of higher level of organisational causes.

- If the higher level factors are not removed from this system, the same incident will continue to occur, even with the best, highly trained operators working at the lower levels.

- What would be middle level causes and barriers (defences)?

- Restrictions for safe behaviour should be identified and removed or minimised.

- Fundamental change is needed to reduce risk within this system (starting with the higher level). Incremental changes will have little impact in the long term.

- The most important is government policy. There should be government agency to do safety check regularly. Check points include physical equipment and manuals, training, etc.

\section{Change}

Culture change: bottom-up
- Design or create a safety culture: an informed culture, a reporting culture; a learning culture; a just culture; a flexible culture.

- Pressure for change should come from the front line and the public. Otherwise culture and structural changes won't come.

- The general public should ask for safety management certificate proof from the ferry company before boarding.

- Perhaps a bottom-up approach of informing the sharp end in such systems they want to operate safely, but don't necessarily feel that they are allowed to or understand the potentials of their actions.

\section{Change}

Safety management system
- Researchers should develop safety management course materials for ferry companies.

- Business should do regular accident training courses.

- Companies should provide manuals and training for staff

- Practice rescue operations 


\section{Discussion}

The first objective of this study was to analyse systematically the South Korea ferry accident using Rasmussen's risk management framework and the associated AcciMap technique. As demonstrated in other studies (Branford, 2011; Jenkins et al., 2010; Johnson and Muniz de Almeida, 2008; Salmon et al., 2010; Vincente and Christoffersen, 2006; Waterson, 2009b; Woo and Vincente, 2003), this study provided additional evidence of the value of the AcciMap in analysing a large-scale accident investigation.

\subsection{Systemic Integration of Piecemeal Information}

This study confirmed that the AcciMap makes it possible to link many of the findings of the government report and numerous news articles in a comprehensive manner. As both Svenson et al. (1999) and Hopkins (2000) identified, this study also highlights how different interested parties and media articles tend to focus on the partial causal factors and biased recommendations that meet with their interest, expertise or their understanding of the situation. Many news articles often addressed failings at only one or two levels in the Rasmussen's risk management framework. Furthermore, the disaster was heavily politicised later and some news articles only highlighted failings of government. The Board of Audit and Inspection report also focused mainly on the misconduct of government agencies. The AcciMap approach in this study provided the capacity to take the full picture into account and represent it.

\subsection{Balanced Representation of Human and Systems Factors}

This study also confirmed that the AcciMap demonstrated a balanced approach to the accident analysis focusing on the mechanisms generating failings in the complex sociotechnical systems, not on finding out who to blame. It showed that factors contributing to the accident include not only actors, conditions and events that ultimately released the accident, but also the combination of a number of interrelated systemic factors and influences (Turner 1978, Reason 1995). For example, a root cause of the 'overdrained ballast water' was attributed to several factors in hierarchical order, such as the inadequate safety operation check by a marine operating inspector, illegal remodelling of the Sewol by Chonghaejin Marine Company, wrong approval for the remodelling by the Incheon RMAS\&PA and KRS, and lack of regulatory provision for the ship remodelling by the MOF. Another example is crew members' lack of seamanship. It might have come from lack of training, their unstable positions as contract workers and low salaries, which were mainly due to the company management policy of prioritizing profits over passengers' safety. The focus on short-term profit might have stemmed from the company's poor financial standing. The Incheon to Jeju ferry line was known to be 
highly profitable, but since much money earned through ferry operating illegally flowed away into the company's owner and his family members, the company was in poor financial condition. As a result, the company had to reduce the budget for safety training for its crew members, and unreasonably expanded and dangerously overloaded the Sewol to maximise profit. The AcciMap helped see the operation of this company in the context of loosely regulated coastal liner business and "rule-bending" and "quick-quick" culture of South Korea society.

It was found that the investigation of this accident in South Korea focused on blaming relevant actors' errors and violations. In the culture characterised by hierarchical, compliance-based relationships like South Korea (Hofstede and Bond, 1988), the common belief is that accountability systems are operationalised in terms of identification of culprits and corresponding threats of disciplinary or criminal proceedings. These beliefs rest on assumptions that remedial and disciplinary actions will produce improvements by increasing the motivation for safe practice (Woods, 2005). Any argument to move beyond a culture of blame can be suspected as a disguised attempt to protect culprits regardless of their positions in the system (operators, managers, regulators or government). The notion that erratic people degrade an otherwise safe system is widespread in this culture and calling to accountability becomes part of the process of identifying and protecting the system from unreliable people at various levels of the system. Once culprits are identified, it is common to invoke methods of remedial training, professional disciplinary action, limits on practice, or even criminal prosecution to improve safety.

Blame in this accident had fallen mainly on crew, the ferry operating company, rescue teams and government officials. Their failings were viewed as root causes of the accident. As a result, the focus of the investigation by the prosecution and the Board of Audit and Inspection of Korea was on errors, violations and misconduct of people. For example, the prosecution arrested the captain of a KCG rescue ship dispatched to the accident site on charge of manslaughter in business for his poor rescue commanding. However, this simple punitive approach has been widely known to have limitations and negative implications, as highlighted in the recommendations by the safety experts of this study.

Dekker (2012) pointed out the hindsight bias effect, a well known research finding relevant to accident analysis. It is common, after an event has occurred, to see the event as having been predictable. The bias lead us to oversimplify the complex situation confronting the people concerned and unfairly blame people. 
The punitive approach provides only a partial/unbalanced view of the hazards and the factors that contribute to accidents (Cook et al., 1998; Vincent and Christoffersen 2006). The accidents cannot be attributed to an error or an one-time threat to safety, but to a combination of systematically-induced migration in work practices and an odd event that wound up revealing the degradation in safety that had been occurring all the time (Vincent and Christoffersen, 2006). Rasmussen (1997) asserted that if just the error or threat to safety had been avoided by some additional safety defences, the accident would still happen by another cause sometimes.

To make matters worse, when adopting the punitive approach, accident investigations tend to end prematurely (Cook et al., 1998). The aim of the investigators becomes to find people responsible and punish them. The investigation ends prematurely when achieving that aim without investigating the variety of organisational and institutional factors that influence the decisions and actions at the sharp end. The risk of ending the investigation early is great.

It is interesting to note that more than half of the safety experts emphasized the importance of forgiving people in this accident and warned the potential negative impact of a one-sided blaming culture, as shown in Table 2. It is understandable given the dominant blame culture prevalent in South Korea after the accident. However, the slogan of moving beyond a blame/punitive culture should not be a blind tolerance for an absence of accountability, but a call to abandon poor systems of accountability and to begin to design a more effective system of accountability (Woods, 2005). Previous research (Woods, 2005), however, demonstrated a dilemma in the system of accountability. Some factors in the reciprocating cycles of accountability may degrade decisions, performance, cooperation and learning, while other relationships in the cycle may enhance these cognitive processes. For example, calling for accountability can increase critical thinking and enhance the quality of action/decision in certain conditions, while it can increase defence behaviour and self-justification and reduce the quality of action/decision in other conditions. It is important to strike a balance between individual accountability and the systemic nature of the accident considering such reciprocating cycles of accountability.

The Rasmussen's risk management framework and the AcciMap analysis in this study helped strike a balance by placing the events that finally released the accident into the necessary context for understanding how and why the accident occurred. The provision of this contextual detail can help avoid unfairly blaming people, because it provides the background of how their activities came about and how these actions were able to release an accident (Branford, 2011). 


\subsection{Dynamic Nature of Safety Migration and Countermeasures}

The findings in this study are in agreement with one of Rasmussen's (1997) predictions. Work practices in a complex socio-technical system are not static and they will migrate over time under the influence of a cost gradient and an effort gradient. The safety migration process usually happens when acute goals like cost and efficiency take precedence over chronic goals like safety as shown in this analysis.

For example the captain worked under at least two competing goals working for maximum profit and a desire for minimum workload. The captain chose a short, but risky route to make up for a two hour delayed departure. At the same time the captain chose to take rest in order to work with minimum workload leaving only a six month experienced third navigating officer alone in the navigating bridge while sailing through the risky route. The captain, in the past, worked under these pressures all the time and managed many successful sails without any accident. He was considered a very competent and experienced captain because he worked for the maximum profit with minimum workload. Before the accident, the Chonghaejin Marine Company received several awards for logistics development. However, the captain did not know how close he was to the safety boundary and continued to work for even higher profit with even lesser workload. Eventually the captain ended up crossing the boundary and alignment with other weaknesses of the whole system led to the accident.

On the other hand, the marine operation inspector was not under the influence of a cost gradient. He was inclined to work with minimum workload, but he did not need to work for the maximum profit since his employer, the KSA, is a non-commercial organisation. Instead, the inspector had conflict of interest and was under socio-political pressure from the KSA's members who are shipping operators. The widespread patronage between present and former government officials in government-affiliated organisations produced safety migration from the socio-political pressure in this accident.

There were so many people involved in this particular accident including ferry crew members, staff and management of the Chonghaejin Marine Company, VTS operators, rescue team members, coast guard, and officials in the KRS, Incheon RMA\&PA and government ministries. The migration of work practices occurred from the combination of economic, workload and socio-political pressures at multiple levels of a complex sociotechnical system, not just one level alone as predicted by Rasmussen (1997).

Given the dynamic nature of safety migration, the target should be to help the whole system maintain high safety despite socio, political and economic pressures. This is the topic of resilience engineering, which was also suggested by some safety experts in this 
study. The authors would like to further discuss the potential implication of this approach in the context of this accident.

In order to counteract safety migration, the ferry transportation system of the future will need a means to recognise when the side effects of socio, political and economic pressures may be increasing safety risks. For example, resilience engineering would monitor evidence on whether effective safety approvals and checks are in place particularly when risky decisions are made. There is a need for a system to monitor its own practices and processes to detect when they are beginning to drift toward safety boundaries. However, when this pattern of drift toward failure is combined with multiple and fragmented stakeholders interacting together in the process, it is very challenging for anyone in the system to see the big picture and its own blind spots about risks. Even if there are monitoring roles in place, confirmation bias (one of the cognitive biases) may make people select for, interpret and focus on information that confirms their preconceptions.

As demonstrated in this analysis, the evidence of risks, e.g. warning signs and signals prior to the accident, became invisible to people so that safety margins eroded over time. For example, the ferry's balance problem was noticed and reported by the crew members, but company officials did not respond to it. Some dockworkers complained about the illegitimate overloading of the cargo and even held a demonstration in front of local government, but the risk was neither detected nor responded to. The crew members also reported the steering gear problem, but the company management disregarded it. As mentioned earlier, it is difficult to judge in hindsight whether people were reckless, negligent or just working hard to deliver under pressure.

In this messy context, the commitment to balance the acute pressures of efficiency and cost with the chronic pressures of safety by people at all levels (operators, managers and regulators) is first and foremost. Their willingness to invest resources in safety and to allocate them to safety management in a timely, proactive manner, despite pressures on efficiency and cost, are key factors in ensuring a safe system.

The analysis also shows the importance of continuous monitoring and balancing the tradeoffs of various pressures and risk. In this sense, it is critical to have an independent and well-informed function with the role of monitoring the risk that the organisation is operating nearer to safety boundaries. In this accident, there were people with that role, e.g. regulators and inspectors, but they were neither independent, nor well-informed.

\subsection{Future Work}

One of the novelties of this study is in the way the AcciMap was used. This study used the AcciMap not only to analyse the accident, but also to communicate the accident with 
the safety experts and to get their recommendations for safety improvement. Describing all of the factors and interrelationships in text would take multiple pages and be difficult to follow. Compiling the information graphically using the AcciMap makes the factors and interactions that resulted in the outcome clear and assists in conveying the information in a succinct way (Branford, 2011). However, many of the experts' recommendations were abstract reflecting their general theoretical stance instead of being based on deep analysis of the accident. A further study with more focus on ease of understanding and usefulness of the AcciMap as a communication and group-based analysis tool is therefore suggested.

There is another important issue for future research. The issue of power was not taken much into account in this analysis. The culture in South Korea has a relatively high degree of power distance (Hofstede, 1984), which often leads to mismatch of responsibility, accountability and authority. For example, one might have the responsibility for certain outcomes, but might not have sufficient authority (power) to influence or control the processes that lead to outcomes, which is called a "double bind" by Woods (2005). This double bind can be shaped implicitly by the conditions laid down at the top of organisations/society. The workers' experience of being disregarded by position power serves as an example of how risk is socially constructed and how power influences the definition of risk and decisions/actions made by people at the lower end of power structure (Antonsen, 2009). Besides, accident analysis and post-accident justice can be influenced by people in power to protect existing structures and arrangements (Dekker, 2012). People without power, status and voice could be on the losing end of justice. This means that justice and power are closely overlapping categories as Dekker (2012) pointed out. This is an important issue for accident analysis in order to achieve new systems of accountability towards high openness to learning and high accountability particularly in countries with a high degree of power distance like South Korea.

\section{Conclusion}

This study aimed to analyse the South Korea ferry accident using Rasmussen's risk management framework and the associated AcciMap technique and to propose recommendations drawn from an AcciMap-based focus group with systems safety experts. This study provided further evidence for of the value of Rasmussen's risk management framework in a large-scale accident investigation: i) systemic integration of piecemeal information about the accident; ii) balanced representation of individual accountability and system factors; iii) dynamic nature of safety migration. This study demonstrated, for the first time, the utility, although limited, of AcciMap as a communication tool in drawing out recommendations from safety experts. Further studies 
need to be carried out in order to further explore the potential of AcciMap as a communication and group-based analysis tool.

The analysis highlighted the importance of having independent and well-informed people with the role of continuously monitoring risk in order to counteract safety migration. The results and methodological framework of this study would provide valuable insights to the Korean accident investigatory agencies such as Ministry of Public Safety and Security, Select Committee of the Sewol Accident and Korea Occupational Safety \& Health Agency where the legacy of Jens Rasmussen's work has yet to reach.

\section{Acknowledgements}

The authors thank the organisers and the participants of 'the legacy of Jens Rasmussen' symposium, Adjunct Symposium of Organisation Design and Management (ODAM) conference 2014. The authors particularly thank those who actively participated in the focus group, including Prof Paul Salmon, Prof Richard Cook, Prof Robert Wears, Dr David Embrey, Prof John Paulin Hansen, Dr Inge Linda Wilms, Prof Lutz Packebusch, Prof Hakan Alm, Prof Xiuzhu Gu, Prof Henning Boje Andersen, Dr Jean-Christophe Lecoze, Jacob Nielsen and Erik Persson. The authors also thank Simon Murray, a chief operating officer of a Greece-based ship operation company for his comments on the AcciMap Analysis and paper. 


\section{References}

Amalberti, R., 2001. The paradoxes of almost totally safe transportation systems. Safety Science. 37, 109-126.

Antonsen, S., 2009. Safety culture and the issue of power. Safety Science. 47(2), 183-191.

Bird, F., 1974. Management guide to loss control, Atlanta, Institute Press, GA.

Brandford, K., 2011. Seeing the big picture of mishaps: Applying the AcciMap approach to analyze system accidents. Aviation Psychology and Applied Human Factors. 1(1), 31-37.

Cook, R.I., Woods, D.D., Miller, C., 1998. A tale of two stories: Contrasting views of patient safety, National Health Care Safety Council of National Patient Safety Foundation at the AMA.

Dekker, S., 2012, Just Culture: Balancing Safety and Accountability, $2^{\text {nd }}$ ed. Ashgate, Aldershot.

Dekker, S., 2014, The Field Guide to Understanding 'Human Error', $3^{\text {rd }}$ ed. Ashgate, Farnham.

Elliott, D., 2009. The Failure of organizational learning from crisis - A matter of life and death? Journal of Contingencies and Crisis Management. 17(3), 157-168.

Elliott, D., Smith, D., 2006. Cultural readjustment after crisis: Regulation and learning from crisis within the UK soccer industry. Journal of Management Studies. 43(2), 289-317.

Heinrich, H.W., Petersen, D., Roos, N., 1980. Industrial accident prevention: A safety management approach, fifth ed. McGraw-Hill, New York.

Hofstede, G., 1984. Cultural Dimensions in Management and Planning. Asia Pacific Journal of Management 1(2), 81-99.

Hofstede, G., Bond, M.H., 1988. The Confucius connection: From cultural roots to economic growth. Organizational Dynamics. 16(4), 5-21.

Hopkins, A., 2000, Lessons from Longford: The Esso Gas Plant explosion, CCH, Sydney.

Hollnagel, E., 2004. Barriers and accident prevention, Ashgate, Aldershot.

Jenkins, D.P., Salmon, P.M., Stanton, N.A., Walker, G.H., 2010. A systemic approach to accident analysis: A case study of the Stockwell shooting, Ergonomics, 53(1), 1-17.

Johnson, C.W., Muniz de Almeida, I., 2008. Extending the borders of accident investigation: applying novel analysis techniques to the loss of the Brazilian space launch vehicle VLS-1 V03. Safety Science. 46(1), 38-53. 
Khatri, N., Brown, G.D., Hicks, L.L., 2009. From a blame culture to a just culture in health care. Health Care Management Review. 34, 4, 312-322.

Leveson, N., 2004. A new accident model for engineering safer systems. Safety Science. 42(4), 237-270.

Norman, D.A., 1993. Things that make us smart: Defending human attributes in the age of the machine, Addison-Wesley, Reading, MA.

OECD, 2007, Work Accidents, in Society at a Glance 2006: OECD Social Indicators, OECD Publishing.

Rasmussen, J., 1997. Risk management in a dynamic society: A modelling problem. Safety Science. 27, 183-213.

Rasmussen, J., Svedung, I., 2000. Proactive risk management in a dynamic society, Swedish Rescue Services Agency, Karlstad, Sweden.

Reason, J., 1990. Human error, Cambridge University Press, New York.

Reason, J., 1995. A systems approach to organizational error. Ergonomics. 38, 1708-1721.

Salmon, P., Williamson, A., Lenné, M., Mitsopoulos-Rubens, E., Rudin-Brown, CM., 2010. Systems-based accident analysis in the led outdoor activity domain: Application and evaluation of a risk management framework. Ergonomics. 53(8), 927-939.

Svedung, I., Rasmussen, J., 2002. Graphic representation of accident scenarios: Mapping system structure and the causation of accidents. Safety Science. 40, 397-417.

Svenson, O., Lekberg, A. and Johansson, A.E.L., 1999, On perspective, expertise and differences in accident analyses: arguments for a multidisciplinary integrated approach. Ergonomics, 42 (11), 1561-1571.

Shappell, S.A., Wiegmann, D.A., 2000. The Human Factors Analysis and Classification System-HFACS, U.S. Department of Transportation, Federal Aviation Administration.

Turner, B.A., 1978. Man-made disasters, Wykeham Publications, London.

Vicente, K.J., Christoffersen, K., 2006. The Walkerton E. coli outbreak: A test of Rasmussen's framework for risk management in a dynamic society. Theoretical Issues in Ergonomics Science. 7(2), 93-112.

Waterson, P., 2009a. A critical review of the systems approach within patient safety research. Ergonomics. 52(10), 1185-1195.

Waterson, P., 2009b. A systems ergonomics analysis of the Maidstone and Tunbridge Wells infection outbreaks. Ergonomics. 52(10), 1196-1205. 
Woo, D.M., Vicente, K.J., 2003. Sociotechnical systems, risk management, and public health: Comparing the North Battleford and Walterton outbreaks. Reliability Engineering and System Safety. 80, 253-269.

Woods, D. D., 2005. Conflicts between Learning and Accountability in Patient Safety, 54 DePaul Law Review. 54(2), 485-502. 


\section{Appendix - A List of Newspaper Articles Used for the Accident Analysis}

1. Financial Times, Bad policy caused the ferry disaster, not bad culture, 2014.4.23.

2. New York Times, In Ferry Deaths, a South Korean Tycoon's Downfall, 2014.7.26.

3. CNN, What went wrong on Sewol?, 2014.5.16.

4. CNN, Angry families scream at South Korean ferry captain, crew as trial begins, 2014.6.10.

5. Yonhap News, 검찰 399명 입건...다시 돌아본 4월 16일 그 날, 2014.10.6.

6. Donga-Ilbo, 선원들, 대피명령땐 승객보다 구조순위 밀릴까봐 조치안해, 2014. 5.16.

7. Donga-Ilbo, [세월호 참사]최초 출동 항공구조사 “선내 정보없었다”, 2014. 8. 13.

8. Donga-Ilbo, "재난보도, 신속성보다 정확성 우선", 2014. 9.17.

9. Chosun-Ilbo, [진도 여객선 침몰 / 드러나는 사고 원인] "船室(선실) 늘리면서 배 균형 무너진 듯", 2014.4.18.

10. Chosun-Ilbo,진도VTS와 세월호 교신 전문, 2014.4.20.

11. Chosun-IIbo, [세월호 참사]"예견된 비극" 하나 둘 풀리는 '침몰의 수수께끼', 2014. 4.20.

12. Chosun-Ilbo, [세월호 참사]과도한 '선령 제한' 연장이 화 불렀나, 2014.4.21.

13. Chosun-Ilbo, [세월호 참사] 급선회 전에 선체내 심각한 무슨일이, 2014. 4.21.

14. Chosun-Ilbo, [세월호 침몰/급선회.전복 원인] "빙판 위 車가 중심 잃듯, 운항미숙 세월 號도 확 돌아간 듯", 2014.4.21.

15. Chosun-Ilbo, 船長의 '굿 시맨십(Good Seamanship)' 결여가 부른 세월호 慘事, 2014. 4.21.

16. Chosun-Ilbo, [사설] 檢·警, '세월호 해운 비리' 뿌리 끝까지 도려내야, 2014.4.22.

17. Chosun-Ilbo, [세월호 참사]"세월호 고박 장비 없었다"...면허도 '임대', 2014.4.23.

18. Chosun-Ilbo, [세월호 참사 / 안전의식 제로 청해진해운] '세월ㅁ⿸⿸⿸⿰丿⿱⺊⺂七七几几 쌍둥이배' 오하마나마⿸⿸⿸⿰丿⿱⺊⺂七七几几(청해진해운의 또다른 인천 제주 여객선)도 구명벌(救命筏·liferaft) 40 개 모두 작동 안해, 2014.4.26.

19. Chosun-IIbo, [세월호 참사 / 관계기관 책임 공방] 세월ㅁ⿸⿸⿸⿰丿⿱⺊⺂七七几几, 화물 적재량의 3 배 싣느라 평형水(균형 잡으려 배에 채우는 물) 덜 채워 균형 잃은 듯, 2014.4.26.

20. Chosun-Ilbo, '그것이 알고싶다' 세월호 침몰 집중 조명, "전직 항해사가 말하는 불편한 진실", 2014.4.26.

21. Chosun-Ilbo, [세월호 참사]국내 여객선 절반은 '개조'했다, 2014.4.28.

22. Chosun-Ilbo,청와대, 정홍원 국무총리 사퇴 수리할 듯 '사고 수습 끝난 후', 2014.4.28.

23. Chosun-Ilbo,"대통령 下野하라" 비판 글에... 청와대홈피 마비, 2014.4.29.

24. Chosun-Ilbo,일부 진보단체·네티즌, 대통령下野 요구·욕설까지, 2014.5.1.

25. Chosun-Ilbo, 관료마피아(1)해피아(해양마피아), 세월호 참사의 책임자들, 2014.5.2. 
26. Chosun-Ilbo, [구멍뜰린 대한민국](4)멈추지 않는 대형사고...6人의 전문가가 말한다, 2014. 5.9.

27. Chosun-Ilbo, 忘却에 저항하라, 2014. 5.10.

28. Chosun-Ilbo, [세월호] 구명벌 정비업자 구속..."선박 안전 검사에 '정상' 판정", 2014. 5.14.

29. Chosun-Ilbo, 진도VTS, 2인 1조 근무 규정 어겨, 2014. 7.4.

30. Chosun-Ilbo, [세월호 참사]가족대책위 "국정원, 세월호 증개축 개입" 주장, 2014.7.25.

31. Chosun-Ilbo,증언석에 선 海警 "선내 진입 훈련 받은 적 없어", 2014. 8.12.

32. Chosun-Ilbo,세월호특별법 9.30 여야 합의문, 2014.9.30.

33. Chosun-Ilbo, 세월호 수사 결과: 무리한 증축·과적·운항 미숙이 세월호 침몰 직접 원인, 2014. 10.7.

34. Chosun-Ilbo, 세월호 참사 209일 만에 실종자 수색작업 종료... "또 다른 희생 우려", 2014. 11.11.

35. Monthly Chosun, [월간조선] “여객선 운항관리 서로 맡지 않으려고...” 海水部 마피아의 고백, 2014.5.20. 